\section{Transfusion Medicine and Hemotherapy}

\title{
Natural Killer Cells for the Treatment of Malignancies*
}

\author{
Torsten Tonn Erhard Seifried
}

Institut für Transfusionsmedizin und Immunhämatologie, DRK Blutspendedienst Baden-Württemberg-Hessen, Johann Wolfgang Goethe Universitätsklinikum Frankfurt am Main, Germany

\section{Key Words}

Adoptive immunotherapy · Natural killer cells · NK-92 .

Cancer · Malignancies

\section{Summary}

For years activated natural killer (A-NK) cells have been explored with respect to their efficacy in anticancer therapy, but except for some anecdotal reports no clear clinical benefit has been shown. However, as the understanding about the interactions of NK cells and tumor cells advance, the use of A-NK cells might be revisited with more sophisticated approaches. The recent discovery of specific receptors on NK cells that interact with HLA molecules on target cells but also the discovery of specific activating receptors have allowed NK cells to step out of the shadow of $\mathrm{T}$ cells to be considered for cellular therapy of malignant diseases. NK cells are a subgroup of lymphoid cells that provide one of the first lines of defense against virus-infected and tumor cells. For clinical use NK cells have to be enriched to deplete contaminating $T$ lymphocytes which is especially important in allogeneic NK cell infusion. Recently attention has been drawn to the clonal NK cell line NK-92, which appears as an attractive alternative for the adoptive immunotherapy of malignancies. NK-92 exhibits high cytotoxicity towards a broad range of tumors, which can be further extended by the recombinant expression of chimeric antigen receptors. This review summarizes the key features of primary and clonal NK cells and their potential use in adoptive immunotherapy of malignancies.

*Dedicated to Prof. Dr. Peter Hanfland, Bonn, on the occasion of his 65th birthday.

\section{Schlüsselwörter \\ Immuntherapie · Natürliche Killerzellen · NK-92 . \\ Malignome · Tumoren}

\section{Zusammenfassung}

Natürliche Killerzellen (NK-Zellen) werden seit Jahren in Bezug auf ihre Einsatzmöglichkeiten und Effizienz als Immuntherapeutikum maligner Erkrankungen untersucht, ohne dass sich bisher signifikante klinische Erfolge erzieIen ließen. Neue Erkenntnisse über die Interaktion von NK-Zellen und Tumorzellen lassen jedoch eine Reanalyse von NK-Zellen sinnvoll erscheinen. Die Entdeckung von spezifischen Rezeptoren auf NK-Zellen, welche mit HLAMolekülen auf Tumorzellen interagieren, aber auch die Entdeckung von spezifischen aktivierenden Rezeptoren haben dazu geführt, dass NK-Zellen aus dem Schatten der T-Lymphozyten herausgetreten sind und für eine Zelltherapie maligner Erkrankungen in Betracht gezogen werden. NK-Zellen sind eine Untergruppe lymphoider Zellen und stellen eine der ersten Wellen der körpereigenen Immunabwehr gegen virusinfizierte Zellen und Tumorzellen dar. Für eine klinische Anwendung müssen NK-Zellen angereichert werden, um kontaminierende TLymphozyten zu depletieren. Dieser Schritt ist insbesondere bei einer allogenen Anwendung von NK-Zellen notwendig. Die klonale NK-Zelllinie NK-92 hat kürzlich ebenfalls Aufmerksamkeit auf sich gezogen und erscheint als attraktive Alternative für die adoptive Immuntherapie von Malignomen. NK-92-Zellen zeichnen sich durch eine hohe Zytotoxizität gegen ein breites Spektrum verschiedener Tumoren aus, welche durch rekombinante Expression von chimären Antigenrezeptoren noch erweitert werden kann. Diese Arbeit gibt eine Übersicht über die Schlüsselfunktionen primärer und klonaler NK-Zellen und ihrem potentiellen Einsatz als adoptives Therapeutikum maligner Erkrankungen.

\begin{tabular}{|c|c|}
\hline KARGER & (c) 2006 S. Karger GmbH, Freiburg \\
\hline $\begin{array}{l}\text { Fax +49 } 7614520714 \\
\text { E-mail Information@Karger.de } \\
\text { www.karger.com }\end{array}$ & $\begin{array}{l}\text { Accessible online at: } \\
\text { www.karger.com/tmh }\end{array}$ \\
\hline
\end{tabular}




\section{Pre-Requisites for Natural Killer Cells to Lyse Malignant Targets}

The occurrence and progression of cancer is linked to a failure of the patients immune response to eradicate tumor cells. Mechanisms allowing tumor cells to escape immunosurveillance by natural killer (NK) and other immune cells may play a major role in tumor progression [1-3]. NK cells are a subgroup of lymphoid cells that provide one of the first lines of defense against virus-infected and tumor cells. They do not rearrange their immune receptor genes, and their cytotoxicity is not MHC-restricted. NK cells mediate spontaneous killing of various tumor cells without prior sensitization. NK cells kill target cells predominantly through release of perforin, which causes target cell permeability followed by DNA disintegration and cell death mediated by esterases such as granzyme B. In addition to direct cytolytic/apoptotic effects mediated by the granzyme/perforin system, some target cell killing occurs through molecules of the TNF superfamily such as Fas/FasL, TRAIL, TWEAK and TNF- $\alpha$. Activity of NK cells towards their malignant targets depends on several parameters, including binding of the respective target cell by cell adhesion molecules (CAMs); regulation of NK cell function orchestrated by an array of activating and inhibitory NK cell receptors (NKRs) and/or the sensitivity of target cells towards cytolytic effectors (perforin, granzyme, Fas-L). Cell-cell contact between NK cells and their target cells is a prerequisite for killing of target cells, and prevention of binding ultimately leads to tumor cell resistance [4]. Attachment of NK cells to target cells initially utilizes CAMs [5]. In addition, CAMs subsequently provide stimulatory signals for the activation of effector cells [4]. The LFA-1/ICAM-1 ligand/receptor pair serves as a dominant adhesion pathway for NK cells. Upon activation the binding affinity of LFA-1 for ICAM-1, and to a lesser extent ICAM-2 and ICAM-3, is rapidly increased.

After binding to its target cell, NK cell activation is further regulated by a balance of signals that are generated from inhibitory and activating receptors [6-9]. MHC class I molecules function as major ligands for a wide array of inhibitory receptors clonally expressed on NK cells. While this mechanism might prevent self-destruction under physiological conditions, up-regulation of certain HLA alleles may allow malignant cells to escape NK cell immunosurveillance. For example, expression of HLA-G, a ligand for KIR2DL4, was reported to protect otherwise susceptible target cells from NK cell lysis [10-13]. In contrast, a mismatch of HLA-C in haploidentical stem cell transplantation (HSCT) results in long-term remission, attributed to a graft-versus-leukemia (GVL) activity of NK cells arising from the transplant [14]. Tumor cells may also evade cytotoxic effector function of NK cells by resistance to perforin/granzyme B-mediated lysis and the induction of apoptosis by utilization of members of the TNF receptor family (Fas, TNF, TRAIL) $[15,16]$. Perforin, as a pore-forming protein, binds to the target cell membrane, leading to loss of
Table 1. Some of the inhibitory and activating NK cell receptors and their ligands

\begin{tabular}{|c|c|}
\hline Receptor & Ligand \\
\hline \multicolumn{2}{|c|}{ Activating NK cell receptors } \\
\hline 2B4 & CD48 \\
\hline NKp44 & influenza/unknown \\
\hline NKp30 & unknown \\
\hline NKp46 & influenza/unknown \\
\hline CD16 & $\operatorname{IgG}$ \\
\hline NKG2D & MIC-A, MIC-B \\
\hline NKp80 & unknown \\
\hline DNAM & CD112/CD155 \\
\hline \multicolumn{2}{|c|}{ Inhibitory NK cell receptors } \\
\hline ILT2 & MIC-A,-B,-G \\
\hline KIR3DL2 & MHC-A \\
\hline KIR3DL1 & MHC-B \\
\hline KIR2DL4 & MHC-A,-B,-G \\
\hline KIR2DL1.2.3 & MHC-C \\
\hline CD94 & MHC-C \\
\hline
\end{tabular}

osmotic stability and influx of granule-associated proteins that are able to induce apoptosis [17]. The binding ability of perforin to leukemic blasts has been reported to correlate with their sensitivity towards NK cell cytotoxicity. Abundant perforin binding results in sensitive targets, whereas reduced binding of perforin was observed in resistant cells $[17,18]$.

\section{Natural Killer Cells in Cancer Therapy}

Sensitization of NK cells is not prerequisite for cytotoxic activity, which on the other hand is enhanced upon activation of NK cells with a variety of cytokines $[19,20]$. These activated NK (A-NK) cells, typically expanded from the peripheral blood and, activated by IL-2, are sometimes also referred to as lymphokine-activated killer (LAK) cells, although the majority $(>90 \%)$ of IL-2-activated blood mononuclear cells represent polyclonal T cells. Recently the term A-NK cells has been introduced due to the fact that adherence and activation is necessary to expand highly lytic NK cells and that an increasing number of different cytokines is reported to activate NK cells [21]. In patients with malignant disorders, NK cell function has been shown to be impaired in terms of a reduced in vitro proliferative response and reduced cytotoxic activity [22, review in 23]. Although dysfunctions in NK cell populations might allow the occurrence and metastasis of tumor cells in these patients [23], there is also evidence that tumor cells themselves may have developed mechanisms to escape NK cell immunosurveillance e.g. by up-regulation of classical (HLA-A,B,C) and nonclassical (HLA-G,E) human lymphocyte antigens (HLA) [24, 25]. These HLA alleles are able to inhibit NK cell function upon ligation with certain killer cell immunoglobulin like receptors (KIRs) on effector cells such as NK cells [26]. 
Fig. 1. NK-92 cells can be retargeted to specific tumor antigens through the expression of chimeric antigen receptors consisting of a scFv antibody fragment (3) with tumor specificity and a signal transduction chain (5) that upon antigen binding links to endogenous signaling pathways and generates activating signals similar to those initiated by the TCR complex. Due to the lack of inhibitory receptors on NK-92 cells (2), the endogenous signaling pathways lead to the release of the lytic enzymes perforin and granzymes (6) that ultimately mediate tumor cell lysis.

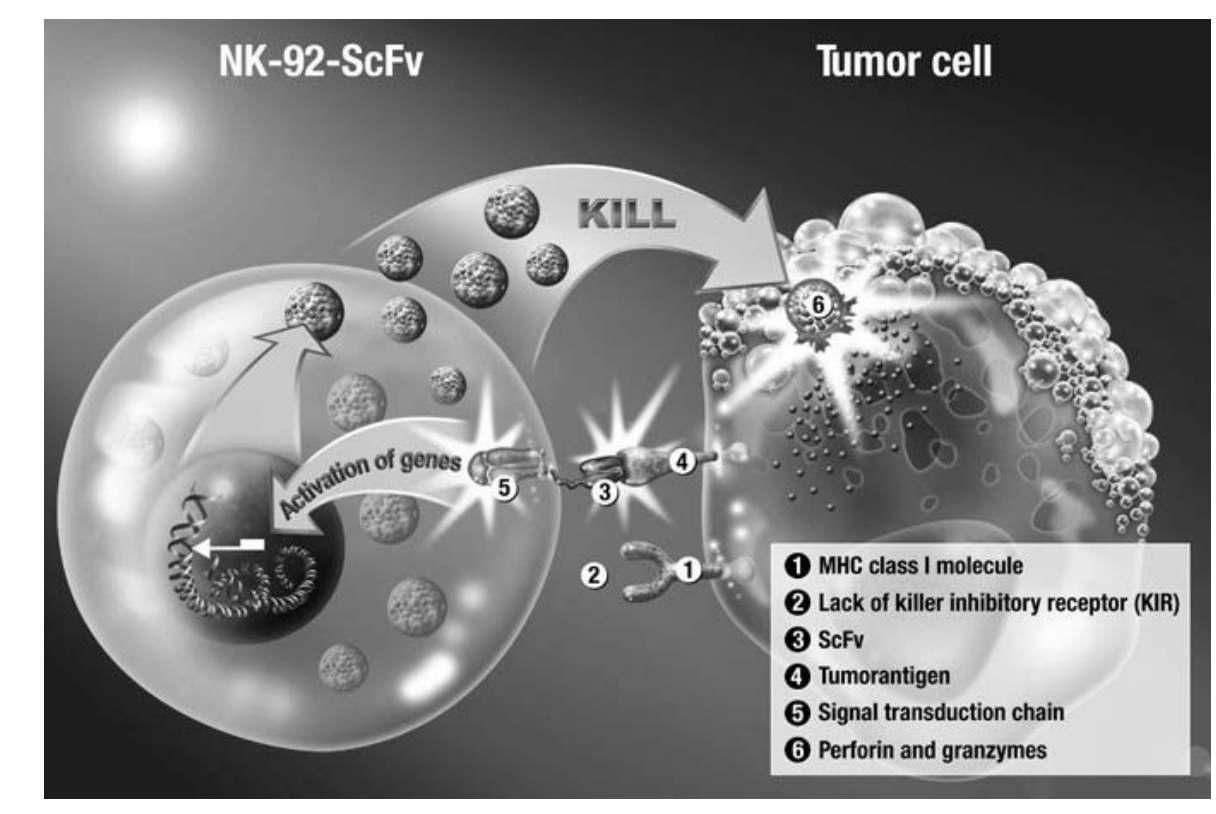

Numerous studies have been conducted and are still ongoing, aiming at improving the antitumor effect of NK cells by either endogenous activation of the patients' own NK cells through administration of cytokines [27-30] or through adoptive use of ex vivo expanded autologous [31-33] or donor-derived [34, 35] A-NK or LAK cells, or a combination thereof $[31,32,36]$. The safety and efficacy of adoptive A-NK cell therapy has been examined in solid [32-34, 36] tumors as well as in hematological malignancies $[31,37]$ where NK cells are used in combination with high-dose chemotherapy to promote the GVL effect without inducing the potentially lethal graft-versus-host reaction which is largely mediated by $\mathrm{T}$ cells. While the systemic application of IL-2 has proved to be less well tolerated in doses necessary to achieve relevant concentrations at the site of the tumor [36], the repeated intravenous transfusion of up to $10^{11} \mathrm{~A}-\mathrm{NK}$ cells in some trials was well tolerated and did not lead to adverse reactions [34]. However, only few patients could benefit from these treatments thus far [23].

\section{Natural Killer Cells and Stem Cell Transplantation}

Recent observations suggest that the ability of leukemia cells to escape immunosurveillance involving NK cells may contribute to the poor outcome of the disease. In HLA-C-mismatched transplantation graft-mediated NK cell cytotoxicity against host leukemia cells in the absence of KIR ligands has been shown to induce long-lasting remission in acute myelocytic leukemia (AML) patients [14]. In contrast, KIR mismatch did not translate into improvement of disease-free survival in acute lymphatic leukemia (ALL), suggesting that ALL blasts exhibit mechanisms of resistance other than - or in addition to - the involvement of KIRs. In NK cell-sensitive leukemias, such as AML, the adoptive immunotherapy using NK cells may therefore promise to induce potent antileukemic effects. Several trials are currently underway to analyze the safety and efficacy of adoptively transfused donor NK cells. Especially in the setting of HSCT from haploidentical donors - where donor lymphocytes can not be used - the adoptive transfer of immunomagnetically purified and CD3-negative NK cells is analyzed with respect to safety and efficacy [38]. It remains to be seen if the beneficial outcome that was retrospectively observed in transplanted patients with a KIR mismatch in graft direction will eventually translate into clinical protocols involving NK-based cell therapies.

\section{Clonal Natural Killer Cell Lines for the Immunotherapy of Malignancies}

To date, only few NK cell lines could be established from patients with large granular lymphoma [review in 39], and although some of them were shown to have maintained cytotoxicity, they differ considerably with regard to the in vitro tumoricidal properties [39, 40]. The most potent and suitable NK cell line with regard to clinical use in cancer and viral infections, seems to be the line NK-92 which was established by H.G. Klingemann who also suggested to use NK-92 cells for immunotherapy of cancer [41]. To date NK-92 cells are the only NK cell line, that continuously has been developed for adoptive immunotherapy in cancer and has entered clinical trials [42]. In contrast to other established NK cell lines, NK92 cells were shown to have superior cytotoxicity to a wide range of tumor cells in vitro and in xenografted human leukemia and malignant melanoma SCID mouse models. The mechanisms which allow NK-92 cells to highly effective recog- 
Fig. 2. Schematic overview of current immunotherapeutic strategies in cancer therapy. The strategies can be subdivided into passive immunotherapies, where the patient's immune system is supported by the administration of effectors such as monoclonal antibodies and or effector cells (direct cancer killing) with defined specificity. In contrast, active immunization strategies (indirect cancer killing) are aiming to boost the patient's own immune system in terms of a vaccination. Both concepts can be further subdivided into strategies that require patient-

specific collection priming and manipulation of the cells (patient-specific therapy) and strategies that allow patient-independent 'off the shelf' therapy. The clonal NK cell line NK-92 and its variants represents the only cellular therapy that can be administered independently from the patient's immunocompetence in a tumor-specific and yet patient-independent manner. nize and eradicate malignant and virus-infected cells without affecting nonmalignant allogeneic cells are not well understood. However, this superior cytotoxicity is likely mediated by the lack of KIR expression on NK-92 cells and the abundant amount of NKRs.

\section{Retargeting of Cytolytic Effector Cells}

Endowing cytolytic effector cells with chimeric antigen receptors was initially developed as a strategy to circumvent the dependence on professional antigen-presenting cells for activation of naïve T cells and bypass MHC-restricted recognition of peptide antigens on target cells as requirement for the initiation of cytolytic effector functions [reviews in 43, 44]. This might help to overcome some of the limitations inherent to adoptive transfer of tumor-infiltrating lymphocytes or lymphokine-activated killer cells such as heterogeneity of effector cell populations and poorly defined target specificity while the principal advantages of a cell-based therapy, i.e. the high intrinsic cytotoxic potential of the effector cells and their capacity to extravasate and home to tumor sites, could be retained. Specificity of chimeric antigen receptors is provided by the incorporation of heterologous binding domains derived from natural ligands or antibodies for direct, MHC-independent recognition of antigens expressed on the surface of target cells. The binding domains are genetically fused to effector molecules derived from proteins that are naturally involved in T-cell signaling such as the T-cell receptor (TCR) alpha and beta chains [45], or components of the TCR-associated CD3 complex $[43,44]$. Upon antigen binding the chimeric receptors link to endogenous signaling pathways and generate activating signals similar to those initiated by the TCR complex. An important improvement in the design of chimeric antigen receptors was to combine antigen recognition and signaling capability in a single chain configuration. For the construction of such chimeric antigen receptors recombinant single chain $\mathrm{Fv}(\mathrm{scFv})$ antibody fragments were genetically fused to different receptor subunits that serve as signaling molecules in lymphocytes. The identification of suitable target antigens on tumor cells is an important prerequisite for such approaches to be successful. Chimeric antigen receptors with specificity for the pancarcinoma antigen TAG-72 expressed by most human adenocarcinomas [46] and carcinoembryonic antigen [47] have been developed for targeting to cancer cells of epithelial origin. Other suitable targets include receptor proteins such as members of the ErbB/epidermal growth factor receptor (EGFR) family. These receptor tyrosine kinases are locat- 
ed at the cell surface and as important signaling molecules allow a cell to respond to extracellular peptide growth factors [48]. Epithelial cells of most organs including normal ovarian epithelium express ErbB2/Her2 at relatively low levels. These levels are substantially elevated in several types of carcinomas. Elevated levels of EGFR and ErbB2/HER2 have been shown to directly contribute to malignancy.

\section{NK-92 Cells Genetically Engineered to Recognize Tumor Antigens}

We have enhanced the antitumoral activity of NK-92 cells and expanded the range of tumor entities suitable for NK-92based therapies by generating genetically modified NK-92 cells (NK-92-scFv(FRP5)-zeta) that express a chimeric antigen receptor specific for the tumor-associated ErbB2/HER2 antigen [49]. The chimeric antigen receptor consists of a recombinant $\mathrm{scFv}$ antibody fragment derived from the ErbB2/HER2-specific antibody FRP5 [56], a flexible hinge region derived form CD8 alpha, and transmembrane and intracellular regions of the CD3 zeta chain (fig. 1).

Modified NK-92-scFv(FRP5)-zeta cells retain the ability of parental NK-92 cells to efficiently lyse malignant cells of hematologic origin, but in addition are now highly active also against cancer cells of epithelial origin. In our recent study 6 out of 7 established tumor cell lines and primary cancer cells originating from human breast as well as ovarian and squamous cell carcinomas, and expressing elevated levels of receptor tyrosine kinases such as ErbB2/HER2 or EGFR were completely resistant to NK-92 mediated lysis, with the remaining cell line being only weakly sensitive [49]. In contrast, all of the ErbB2/HER2-overexpressing, NK-92-resistant cells and cell lines were efficiently lysed by NK-92-scFv(FRP5)-zeta cells. These results indicate that grafted recognition of tumor antigens by NK-92 cells is capable to overcome tumor cell resistance. Currently we are working to broaden the specificity of NK-92 cells towards otherwise resistant hematologic malignancies such as B-cell acute lymphoblastic leukemia (B-ALL) by grafting NK-92 cells with CD19 scFv [50].

\section{Conclusion and Outlook}

As with other cellular immunotherapies (fig. 2), the tumor burden seems to be critical for the clinical outcome of adoptive therapies with NK cells. However, based on the safety data obtained with recent clinical studies employing highly enriched, T-cell-depleted NK cells or clonal NK cell lines, adoptive immunotherapy of malignancies with NK cells should be viewed as part of a comprehensive cancer treatment approach that may include conventional and experimental therapies. With better insight into the mechanisms by which NK cells mature, the function of different NK cell subsets, and the cross-talk of these cells with dendritic cells and T lymphocytes, more rational approaches in adoptive immunotherapy against primary tumors and their metastases will eventually be possible.

\section{Acknowledgements}

This work was supported by grant No $\mathrm{R}(00 / 02)$ from the Jose Carreras Foundation and a grant of the 'Stiftung Hämotherapie-Forschung' to Torsten Tonn.

\section{References}

1 Teichmann JV, Ludwig WD, Thiel E: Cytotoxicity of interleukin 2-induced lymphokine-activated killer (LAK) cells against human leukemia and augmentation of killing by interferons and tumor necrosis factor. Leuk Res 1992;16(3):287-98.

2 Pawelec G: MHC-unrestricted immune surveillance of leukemia. Cancer Biother 1994;9(3): 265-88.

3 Dokhelar MC, Wiels J, Lipinski M, Tetaud C, Devergie A, Gluckman E, Tursz T: Natural killer cell activity in human bone marrow recipients: early reappearance of peripheral natural killer activity in graft-versus-host disease. Transplantation 1981;31 (1):61-5.

4 Maki G, Krystal G, Dougherty G, Takei F, Klingemann HG: Induction of sensitivity to NK-mediated cytotoxicity by TNF-alpha treatment: possible role of ICAM-3 and CD44. Leukemia 1998;12(10): $1565-72$.

5 Storkus WJ, Dawson JR: Target structures involved in natural killing (NK): characteristics, distribution, and candidate molecules. Crit Rev Immunol 1991; 10(5):393-416.
6 Smyth MJ, Hayakawa Y, Takeda K, Yagita H: New aspects of natural-killer-cell surveillance and therapy of cancer. Nat Rev Cancer 2002;2(11):850-61.

7 Rajagopalan S, Long EO: A human histocompatibility leukocyte antigen (HLA)-G-specific receptor expressed on all natural killer cells. J Exp Med 1999;189(7):1093-100.

8 Ponte M, Cantoni C, Biassoni R, Tradori-Cappai A, Bentivoglio G, Vitale C, Bertone S, Moretta A, Moretta L, Mingari MC: Inhibitory receptors sensing HLA-G1 molecules in pregnancy: decidua-associated natural killer cells express LIR-1 and CD94/NKG2A and acquire p49, an HLA-G1-specific receptor. Proc Natl Acad Sci U S A 1999;96 (10):5674-9.

9 Lanier LL: Natural killer cells fertile with receptors for HLA-G? Proc Natl Acad Sci U S A 1999;96 (10):5343-5.

10 Chumbley G, King A, Robertson K, Holmes N, Loke YW: Resistance of HLA-G and HLA-A2 transfectants to lysis by decidual NK cells. Cell Immunol 1994;155(2):312-22.
11 Pazmany L, Mandelboim O, Vales-Gomez M, Davis DM, Reyburn HT, Strominger JL: Protection from natural killer cell-mediated lysis by HLA-G expression on target cells. Science 1996;274(5288): 792-5.

12 Mandelboim O, Pazmany L, Davis DM, ValesGomez M, Reyburn HT, Rybalov B, Strominger JL: Multiple receptors for HLA-G on human natural killer cells. Proc Natl Acad Sci U S A 1997;94 (26):14666-70.

13 Navarro F, Llano M, Bellon T, Colonna M, Geraghty DE, Lopez-Botet M: The ILT2(LIR1) and CD94/NKG2A NK cell receptors respectively recognize HLA-G1 and HLA-E molecules co-expressed on target cells. Eur J Immunol 1999;29(1) 277-83.

14 Ruggeri L, Capanni M, Urbani E, Perruccio K, Shlomchik WD, Tosti A, Posati S, Rogaia D, Frassoni F, Aversa F, Martelli MF, Velardi A: Effectiveness of donor natural killer cell alloreactivity in mismatched hematopoietic transplants. Science 2002;295(5562):2097-100. 
15 Trapani JA, Davis J, Sutton VR, Smyth MJ: Proapoptotic functions of cytotoxic lymphocyte granule constituents in vitro and in vivo. Curr Opin Immunol 2000;12(3):323-9.

16 Kagi D, Ledermann B, Burki K, Seiler P, Odermatt B, Olsen KJ, Pdack ER, Zinkernagel RM, Hengartner H: Cytotoxicity mediated by $\mathrm{T}$ cells and natura killer cells is greatly impaired in perforin-deficient mice. Nature 1994;369(6475):31-7.

17 Lehmann C, Zeis M, Uharek L: Activation of natural killer cells with interleukin 2 (IL-2) and IL-12 increases perforin binding and subsequent lysis of tumour cells. Br J Haematol 2001;114(3):660-5.

18 Lehmann C, Zeis M, Schmitz N, Uharek L: Impaired binding of perforin on the surface of tumor cells is a cause of target cell resistance against cytotoxic effector cells. Blood 2000;96(2):594-600.

19 Uharek L, Zeis M, Glass B, Steinmann J, Dreger P, Gassmann W, Schmitz N, Muller-Ruchholtz W: High lytic activity against human leukemia cells after activation of allogeneic NK cells by IL-12 and IL-2. Leukemia 1996:10:1758-1764.

20 Son YI, Dallal RM, Mailliard RB, Egawa S, Jonak ZL, Lotze MT: Interleukin-18 (IL-18) synergizes with IL-2 to enhance cytotoxicity, interferongamma production, and expansion of natural killer cells. Cancer Res 2001;61(3):884-888.

21 Vujanovic NL, Rabinowich H, Lee YJ, Jost L, Herberman RB, Whiteside TL: Characteristic of human natural killer cells obtained by rapid interleukin 2-induced adherence to plastic. Cellular Immunol 1993;151:133-157.

22 Sedlmayr P, Rabinowich H, Elder EM, Ernstoff MS, Kirkwood JM, Herberman RB, Whiteside TL Depressed ability of patients with melanoma or renal cell carcinoma to generate adherent lymphokine-activated killer cells. J Immunother 1991; 10(5):336-346.

23 Whiteside TL, Vujanovic NL, Herberman RB: Natural killer cells and tumor therapy. Curr Top Microbiol Immunol1998;230:221-244.

24 Fukushima Y, Oshika Y, Nakamura M, Tokunaga T, Hatanaka H, Abe Y, Yamazaki H, Kijima H, Ueyama Y, Tamaoki N: Increased expression of human histocompatibility leukocyte antigen-G in colorectal cancer cells. Int J Mol Med 1998;2: 349-351.

25 Carosella ED, Paul P, Moreau P, Rouas-Freiss: HLA-G and HLA-E: fundamental and pathophysiological aspects. Immunol Today 2000;21(11): 532-534.

26 Raulet D: Regulation of the natural killer cell receptor repertoire. Annu Rev Immunol 2001;19: 9001-9010.

27 Maraninchi D, Vey N, Viens P, Stoppa AM, Archimbaud E, Attal M, Baume D, Bouabdallah R, Demeoq F, Fleury J, Michallet M, Olive D, Reiffers J, Sainty D, Tabilio A, Tiberghien P, Brandely M, Hercend T, Blaise D: A phase II study of interleukin-2 in 49 patients with relapsed refractory acute leukemia. Leuk Lymphoma 1998;31(3-4) 343-349.
28 Chang E, Rosenberg SA: Patients with melanoma metastases at cutaneous and subcutaneous sites are highly susceptible to interleukin-2-based therapy. J Immunother 2001;24(1):88-90.

29 Mulatero CW, Penson RT, Papamichael D, Gower NH, Evans M, Rudd RM: A phase II study of combined intravenous and subcutaneous interleukin-2 in malignant pleural mesothelioma. Lung Cancer 2001;31(1):67-72

30 Westermann J, Reich G, Kopp J, Haus U, Dorken B, Pezzutto A: Granulocyte/macrophage-colonystimulating-factor plus interleukin-2 plus interferon alpha in the treatment of metastatic renal cell carcinoma: a pilot study. Cancer Immunol Immunother 2001;49(11):613-620.

31 Benyunes MC, Massumoto C, York A, Higuchi CM, Buckner CD, Thompson JA, Petersen FB, Fefer A: Interleukin-2 with or without lymphokineactivated killer cell as consolidative immunotherapy after autologous bone marrow transplantation for acute myelogenous leukemia. Bone Marrow Transplant 1993;12(2):159-163.

32 Hayes RL, Koslow M, Hiesiger EM, Hymes KB, Hochster HS, Moore EJ, Pierz DM, Chen DK, Budzilovich GN, Ransohoff J: Improved long term survival after intracavitary interleukin-2 and lymphokine-activated killer cells for adults with recurrent malignant glioma. Cancer 1995;76(5):840-852.

33 Fujimiya Y, Suzuki Y, Katakura R, Ohno T: Injury to autologous normal tissues and tumors mediated by lymphokine-activated killer (LAK) cells generated in vitro from peripheral blood mononuclear cells of glioblastoma patients. J Hematother 1999;8 (1):29-37.

34 Kimoto Y, Tanaka T, Tanji Y, Fujiwara A, Taguchi T: Use of human leukocyte antigen-mismatched allogeneic lymphokine-activated killer cells and interleukin-2 in the adoptive immunotherapy of patients with malignancies. Biotherapy 1994;8(1): 41-50.

35 Nagayama H, Takahashi S, Takahashi T, Ogami K, Ikebuchi K, To Tani K, Asano S: IL-2/LAK therapy for refractory acute monoblastic leukemia relapsing after unrelated allogeneic bone marrow transplantation. Bone Marrow Transplant 1999;23(2): 183-185.

36 Rosenberg SA, Lotze MT, Yang JC, Topalian SL, Chang AE, Schwartzentruber DJ, Aebersold P, Leitman S, Linehan WM, Seipp CA: Prospective randomized trial of high-dose interleukin-2 alone or in conjunction with lymphokine-activated killer cells for the treatment of patients with advanced cancer. J Natl Cancer Inst 1993;85(8):622-632.

37 Klingemann HG: Relevance and potential of natural killer cells in stem cell transplantation. Biol Blood Marrow Transplant 2000;6(2):90-99.
38 Koehl U, Sorensen J, Esser R, Zimmermann S, Gruttner HP, Tonn T, Seidl C, Seifried E, Klingebiel T, Schwabe D: IL-2 activated NK cell immunotherapy of three children after haploidentical stem cell transplantation. Blood Cells Mol Dis 2004:33(3):261-6.

39 Drexler HG, Matsuo Y: Malignant hematopoietic cell lines: in vitro models for the study of natural killer cell leukemia-lymphoma. Leukemia 2000;14: 777-782.

40 Yan Y, Steinherz P, Klingemann HG, Dennig D, Childs BH, McGuirk J, O'Reilly RJ: Antileukemia activity of a natural killer cell line against human leukemia. Clin Cancer Res 1998;4:2859-2868.

41 Gong JH, Maki G, Klingemann HG: Characterization of a human cell line (NK-92) with phenotypical and functional characteristics of activated natural killer cells. Leukemia 1994;8:652-658.

42 Tonn T, Becker S, Esser R, Schwabe D, Seifried E: Cellular immunotherapy of malignancies using the clonal natural killer cell line NK-92. J Hematother Stem Cell Res 2001;10(4):535-44

43 Eshhar Z: Tumor-specific T-bodies: towards clinica application. Cancer Immunol Immunother 1997;45: 131-136.

44 Uherek C, Groner B, Wels W: Chimeric antigen receptors for the retargeting of cytotoxic effector cells. J Hematother Stem Cell Res 2001;10:523-534.

45 Gross G, Waks T, Eshhar Z: Expression of immunoglobulin-T-cell receptor chimeric molecules as functional receptors with antibody-type specificity. Proc Natl Acad Sci U S A 1989;86:10024-10028.

46 McGuiness RP, Ge Y, Ptel SD, Kashmiri SV, Lee HS, Hand PH, Schlom J, Finer MH, McArthur JG: Anti-tumor activity of human T cells expressing the CC49-zeta chimeric immune receptor. Hum Gene Ther 1999;10:165-173

47 Darcy PK, Hynes NM, Snook MB, Trapani JA, Cerruti L, Jane SM, Smyth MJ: Redirected perforin-dependent lysis of colon carcinoma by ex vivo genetically engineered CTL. J Immunol 2000;164 3705-3712.

48 Yarden Y, Sliwkowski MX: Untangling the ErbB signalling network. Nat Rev Mol Cell Biol 2001;2: 127-137.

49 Uherek C, Tonn T, Uherek B, Becker S, Schnierle B, Klingemann HG, Wels W: Retargeting of natural killer-cell cytolytic activity to ErbB2-expressing cancer cells results in efficient and selective tumor cell destruction. Blood 2002;100(4):1265-73.

50 Romanski A, Bug G, Becker S, Kampfmann M, Seifried E, Hoelzer D, Oliver G. Ottmann, Tonn T: Multiple mechanisms of resistance to NK cellmediated cytotoxicity are not operable in acute lymphoblastic leukemia. Exp Hematol 2005;3(3): 344-52. 